\title{
Implementation of the Student Facilitator and Explaining Model in Learning Skills of Reading Skills in SD
}

\author{
Endang Sri Maruti ${ }^{1}$ \\ ${ }^{1}$ (PGSD, FKIP, Universitas PGRI Madiun, Indonesia)
}

*Corresponding Author. E-mail:marutiendang@gmail.com

\begin{tabular}{|l|l|l|}
\hline Receive: 12/02/2019 & Accepted: 22/03/2019 & Published: 02/04/2019
\end{tabular}

\begin{abstract}
Abstrak
Tujuan penelitian ini adalah untuk mengetahui sejauh mana keterlaksanaan model pembelajaran Model Students Facilitator And Explaining melalui media buku cerita bergambar dalam meningkatkan keterampilan membaca permulaan pada siswa kelas I SDN 01 Taman Kota Madiun Tahun Pelajaran 2018/2019. Penelitian ini termasuk jenis penelitian kualitatif deskriptif. Dengan menggunakan pendekatan fenomenologi. Teknik pengumpulan data didasarkan pada sumber data yaitu RPP, silabus, observasi, wawancara. Angket tertutup. Dokumentasi. Teknik analisis data yang digunakan adalah analisis data model Miles dan Huberman. Berdasarkan hasil penelitian dapat disimpulkan bahwa dalam Penerapan model pembelajaran Students Facilitator and Explaining dengan menggunakan media buku cerita bergambar ini dalam pelajaran bahasa Indonesia tergolong inovatif. Berdasarkan hasil wawancara, dokumentasi, observasi maupun pemberian angket. Respon siswa dikategorikan baik, antusias siswa dalam mempelajari pelajaran bahasa Indonesia menjadi meningkat. Siswa menjadi gemar belajar dan kerjasama siswa juga terbentuk dalam kegiatan berkelompok sehingga mampu menumbuhkan sikap positif terhadap siswa dalam interaksi sosialnya.
\end{abstract}

Kata Kunci: Model Students Facilitator And Explaining, keterampilan membaca permulaan, siswa kelas 1 SD

\section{Implementation of The Student Facilitator And Explaining Model In Learning Skills of Reading Skills In SD}

\begin{abstract}
The purpose of this study was to determine the extent of the implementation of the Student Facilitator Model and Explaining learning model through the media of illustrated story books in improving initial reading skills for first grade students of SDN 01 Taman Kota Madiun 2018/2019 Academic Year. This research includes descriptive qualitative research. By using the phenomenology approach. Data collection techniques are based on data sources, namely RPP, syllabus, observation, interviews. Closed questionnaire. Documentation. The data analysis technique used is the data analysis model of Miles and Huberman. Based on the results of the study, it can be concluded that in the Implementation of the Student Facilitator and Explaining learning model using media illustrated storybooks in
\end{abstract}


Indonesian language lessons are innovative. Based on the results of interviews, documentation, observation and giving questionnaires. Student responses are categorized as good, students' enthusiasm in learning Indonesian language lessons is increasing. Students become fond of learning and student collaboration is also formed in group activities so as to be able to foster a positive attitude towards students in their social interactions.

Keywords: The Student Facilitator; Explaining model, reading skills, $1^{\text {st }}$ grade students

\section{Pendahuluan}

Dalam kurikulum pendidikan dasar dikemukakan bahwa pendidikan yang diselenggarakan Sekolah Dasar (SD) bertujuan memberikan bekal kemampuan dasar baca, tulis dan berhitung (calistung). Pengetahuan dan keterampilan dasar yang bermanfaat bagi siswa sesuai dengan tingkat perkembangannya, serta mempersiapkan mereka untuk mengikuti pendidikan di jenjang pendidikan SMP. Keterampilan baca tulis khususnya harus dikuasai oleh para siswa SD/MI. Keberhasilan belajar mereka dalam mengikuti proses kegiatan belajar disekolah sangat ditentukan oleh penguasaan kemampuan membaca.

Membaca pada dasarnya adalah suatu proses yang dilakukan dan digunakan oleh pembaca untuk memperoleh pesan, yang hendak disampaikan oleh penulis melalui media kata-kata/bahasa tulis. Membaca dapat pula dianggap sebagai suatu proses untuk memahami yang tersirat dalam yang tersurat, melihat pikiran yang terkandung di dalam kata-kata yang tertulis.

Pembinaan kemampuan membaca secara formal dilaksanakan dalam mata pelajaran bahasa Indonesia. Menurut Kurikulum Tingkat Satuan Pendidikan (KTSP) dalam mata pelajaran bahasa Indonesia, standar kompetensi khusunya membaca permulaan menuntut siswa untuk mampu membaca huruf, suku kata, dan kalimat. Pembelajaran Bahasa Indonesia di SD/MI dilaksanakan sesuai dengan perbedaan atas kelas rendah dan kelas tinggi. Pelajaran dikelas rendah biasanya disebut sebagai pelajaran membaca permulaan, sedangkan di kelas tinggi disebut sebagai pelajaran membaca lanjutan. Pelajaran membaca permulaan bertujuan agar siswa mengenal dan merangkai huruf sehingga mereka dapat membaca dengan menggunakan kata tersebut.

Dalam setiap jenjang kelas SD/MI, tidak menutup munculnya kasus kesulitan belajar bagi siswa. Namun, penanganan terhadap mereka belum seperti yang diharapkan. Banyak faktor yang mempengaruhi keterlambatan perkembangan anak berkesulitan belajar. Selain keterbatasan sarana pembelajaran, juga disebabkan kurangnya keterampilan guru dalam mengidentifikasi terhadap mereka, terutama kesulitan belajar membaca permulaan.

Kesulitan membaca permulaan menjadi penyebab utama kegagalan anak di sekolah. Kemampuan membaca permulaan merupakan kebutuhan dasar, karena sebagian informasi disajikan dalam bentuk tertulis dan hanya diperoleh dengan melalui membaca. Adapun tujuan dari membaca permulaan adalah agar anak dapat mengenal tulisan sebagai simbol dan lambang bahasa sehingga anak-anak dapat menyuarakan tulisan tersebut. Agar siswa menjadi aktif dan antusias siswa dalam mengikuti pembelajaran meningkat, maka guru mencoba menggunakan suatu strategi pembelajaran yang diharapkan strategi ini bisa menjadi acuan dan motivator dalam memberikan pembelajaran yang menarik dan menyenangkan sehinggga mampu menumbuhkan sikap disiplin, dan mandiri dalam mengikuti pembelajaran.

Model Students Facilitator And Explaining adalah model pembelajaran dimana guru mampu menyajikan atau 
mendemonstrasikan materi di depan siswa lalu memberikan mereka kesempatan untuk menjelaskan kepada teman-temanya. Jadi model pembelajaran ini merupakan rangkaian penyajiaan materi ajar yang diawali dengan penjelasan secara terbuka, memberi kesempatan siswa untuk menjelaskan kembali kepada reakanrekannya, dan diakhiri dengan penyampaian semua materi kepada siswa (Huda, 2013 : 228).

Media buku cerita bergambar adalah buku yang memuat pesan melalui ilustrasi yang berupa gambar dan tulisan. Gambar dan tulisan tersebut merupakan kesatuan dari cerita untuk menyampaikan fakta atau gagasan tertentu. Dalam cerita bergambar ditulis dengan gayabahasa ringan, cenderung dengan gaya obrolan, isi dalam ceritanya berkenaan dengan pribadi/pengalaman pribadi. Dengan cerita bergambar dapat mendorong bagi anak terhadap minat membaca.

Pada pemelajaran membaca permulaan terdapat beberapa kegiatan yang dilakukan dalam pengajaran membaca, sebagaiman dikemukakan berikut ini: (1) peningkatan ucapan,(2) kesadaran fonetik (bunyi), (3) hubungan antar bunyi-huruf, (4) kemampuan mengingat, (5) orientasi dari kiri ke kanan, dan (6) ketrampilan kosa kata dan makna kata (Ismawati dan Umaya, 2012: 51).

Berdasarkan beberapa definisi tentang membaca di atas dapat disimpulkan bahwa membaca permulaan adalah suatu aktivitas untuk mengenalkan rangkaian huruf dengan bunyi-bunyi bahasa. Membaca permulaan yang menjadi acuan adalah membaca merupakan proses recording dan decoding. Melalui proses recording, pembaca mengasosiasikan gambar-gambar bunyi beserta kombinasinya itu dengan bunyi-bunyian. Dengan proses tersebut, rangkaian tulisan yang dibacanya menjelma menjadi rangkaian bunyi bahasa dalam kombinasi kata, kelompok kata, dan kalimat sederhana.
Model pembelajaran Students Facilitator and Explaining ialah model pembelajaran yang menekankan rangkaian penyajian materi ajar yang diawali dengan penjelasan secara terbuka, memberi kesempatan siswa untuk menjelaskan kembali kepada rekan-rekannya, dan diakhiri dengan penyampaian semua materi kepada siswa sehingga model pembelajaran ini melatih siswa bicara menyampaikan ide dan gagasan.

Huda (2014: 228-229) menyebutkan beberapa sintaks tahap-tahap model pembelajaran Student Faciltator and Explaining adalah guru menyampaikan kompetersi yang ingin dicapai, guru memeragakan atau menyajikan inti dari materi yang akan diajarkan, guru memberi kesempatan kepada siswa untuk menjelaskan kembali kepada teman lainnya, guru menyimpulkan pendapat siswa, dan guru menutup pembelajaran.

Pada kenyataannya kemampuan membaca permulaan siswa terutama pada siswa kelas SDN 01 Taman Kota Madiun masih rendah. Hal ini dapat terlihat dari sekitar $70 \%$ anak yang belum mampu membedakan huruf yang memiliki bunyi ataupun bentuk yang mirip. Rendahnya kemampuan membaca permulaan siswa dimungkinkan karena proses belajar mengajar yang hanya berpusat kepada guru, sehingga siswa tidak ikut terlibat secara aktif dalam proses belajar mengajar tersebut. Untuk meningkatkan kemampuan membaca permulaan maka guru sebaiknya menggunakan model pembelajaran Students Facilitator and Explainingdan media pembelajaran Buku Cerita Bergambar.

Model pembelajaran Students Facilitator and Explaining adalah model pembelajaran yang menekankan rangkaian penyajian materi ajar yang diawali dengan penjelasan secara terbuka, memberi kesempatan siswa untuk menjelaskan kembali kepada rekan-rekannya, dan diakhiri dengan penyampaian semua materi kepada siswa sehingga model pembelajaran ini melatih siswa bicara menyampaikan ide dan gagasan. Sedangkan media 
pembelajaran

Buku

Cerita

Bergambarsebuah media pembelajaran yang menggunakan suatu buku bacaan yang berisikan kartun yang mengungkapkan suatu karakter dan memerankan suatu cerita dalam urutan yang erat, dihubungkan dengan gambar dan dirancang untuk memberikan hiburan kepada para pembaca. Dengan penggunaan model pembelajaran dan media pembelajaran tersebut diyakini dapat meningkatkan kemampuan membaca permulaan karena dalam pembelajaran ini siswa dituntut berperan aktif, tidak hanya menerima materi dan menjawab pertanyaan dari guru. Dengan adanya proses pembelajaran yang menuntut siswa untuk berpikir kritis, maka tidak menutup kemungkinan materi yang dipelajari akan tetap diingat oleh siswa.

\section{Metode}

Tujuan dari penelitian ini adalah untuk mendeskripsikan penerapan metode pembelajaran Students Facilitator and Explaining dan media buku cerita bergambar kelas 1 SDN 01 Taman Kota Madiun. Sehingga, jenis penelitian yang digunakan dalam penelitian ini adalah penelitian kualitatif deskriptif dengan menggunakan pendekatan fenomenologi.

Sesuai yang dikemukakan oleh Bogdan dan Taylor (dalam Moleong, 2014: 4) metodologi kualitatif sebagai prosedur penelitian yang menghasilkan data deskriptif berupa kata-kata tertulis atau lisan dari orang-orang dan perilaku yang dapat diamati. Data yang terkumpul berbentuk kata-kata atau gambar, sehingga tidak menekankan pada angka. Selain itu, penelitian kualitatif lebih menekankan pada proses dari pada produk atau outcome.

Dalam penelitian ini, teknik pengumpulan data yang digunakan adalah teknik dokumentasi, observasi, wawancara, dan angket. Data yang diperlukan dalam penelitian ini adalah data yang berupa dokumen yang meliputi : silabus dan rencana pelaksanaan pembelajaran (RPP), hasil angket untuk mengetahui respon siswa terhadap pembelajaran Bahasa Indonesia menggunakan/model Students Facilitator and Explaining dan media buku cerita bergambar, data pembelajaran Bahasa Indonesia khususnya pada membaca permulaan.

Dalam penelitian ini untuk mengecek keabsahan data dengan menggunakan trianggulasi sumber dapat dicapai salah satunya dengan membandingkan data yang diperoleh melalui hasil wawancara yang dilakukan dengan kepala sekolah dengan data hasil wawancara yang dilakukan dengan wali kelas dan siswa.

Dalam penelitian ini teknik analisis data yang digunakan adalah analisis data model Miles and Huberman. Dimana dalam teknik analisis ini ada tiga yang dilalui untuk melakukan analisi data kualitatif.

\section{Hasil dan Pembahasan}

Pada bab ini secara berturut-turut akan dijelaskan (a) perencanaan model pembelajaran students facilitator and explaining dengan menggunakan media buku cerita bergambar pada pembelajaran bahasa Indonesia, (b) penerapan model pembelajaran students facilitator and explaining dengan menggunakan media buku cerita bergambar (c) respon siswa terhadap model pembelajaran students facilitator and explaining dengan menggunakan media buku cerita bergambar pada pelajaran bahasa Indonesia.

1. Perencanaan Pembelajaran Membaca Permulaan dengan Model Pembelajaran Students Facilitator and Explaining melalui Media Buku Cerita Bergambar

Membaca permulaan pada dasarnya adalah suatu proses yang dilakukan dan digunakan oleh pembaca untuk memperoleh pesan, yang hendak disampaikan oleh penulis melalui media kata-kata/bahasa tulis. Menurut Tarigan (2008: 8) membaca adalah sebagai suatu metode yang kita pergunakan untuk berkomunikasi dengan diri kita sendiri dan 
kadang-kadang dengan orang lain yaitu mengkomunikasikan makna yang terkandung atau tersirat pada lambanglambang tertulis. Kemampuan membaca permulaan merupakan kebutuhan dasar, karena sebagian informasi disajikan dalam bentuk tertulis dan hanya diperoleh dengan melalui membaca. Jadi dalam pembelajaran membaca permulaan diperlukan model pembelajaran dan media pembelajan yang benar-benar tepat dan sesuai dengan kondisi juga karakter siswanya,adapun tujuan tersebut agar anak dapat mengenal tulisan sebagai simbol dan lambang bahasa, sehingga anak-anak dapat menyuarakan tulisan dengan baik.

Model pembelajaran Students Facilitator and Explaining melalui media buku cerita bergambar merupakan model pembelajaran dan media yang akan diterapkan dalam penelitian ini, karena model Students Facilitator and Explaining merupakan model pembelajaran yang mampu menumbuhkan keaktifan siswa dalam proses pembelajaran. Menurut Huda (2013 :228) Model Students Facilitator And Explaining adalah model pembelajaran dimana guru mampu menyajikan atau mendemonstrasikan materi di depan siswa lalu memberikan mereka kesempatan untuk menjelaskan kepada teman-temanya. Jadi model pembelajaran ini merupakan rangkaian penyajiaan materi ajar yang diawali dengan penjelasan secara terbuka, memberi kesempatan siswa untuk menjelaskan kembali kepada reakanrekannya, dan diakhiri dengan penyampaian semua materi kepada siswa, sehinggga mampu menumbuhkan sikap disiplin, dan mandiri dalam mengikuti pembelajaran.

Sedangkan media buku cerita bergambar adalah buku yang memuat pesan melalui ilustrasi yang berupa gambar dan tulisan. Gambar dan tulisan tersebut merupakan kesatuan dari cerita untuk menyampaikan fakta atau gagasan tertentu. Dalam cerita bergambar ditulis dengan gaya bahasa ringan, cenderung dengan gaya obrolan, isi dalam ceritanya berkenaan dengan pribadi/pengalaman pribadi.
Menurut Rohani (2014: 77-78) buku cerita bergambar atau komik mempunyai sifat yang sederhana, jelas, mudah dan bersifat personal,buku cerita bergambar atau komik adalah suatu kartun yang mengungkapkan suatu karakter dan memerankan suatu cerita dalam urutan yang erat, dihubungkan dengan gambar dan dirancang untuk memberikan hiburan pada para membaca, komik adalah suatu bentuk berita bergambar, terdiri atas berbagai situai cerita bersambung, kadang bersifat humor. Perwatakan lain dari komik adalah harus dikenalagar kekuatan medium bisa dihayati.Dengan media buku cerita bergambar dapat mendorong bagi anak terhadap minat membaca.

$$
\text { Adapun perencanaan model }
$$
pembelajaran student facilitator and explaining dan media buku cerita bergambaryaitu guru menyiapkan seperangkat perangkat pembelajaran. Perangkat pembelajaran berupa Rencana Pelaksanaan Pembelajaran (RPP) menggunakan KTSP dimana di dalamnya sudah mencantumkan karakter-karakter yang akan dikembangkan dan ditanamkan pada siswa. Namun sekolah ini belum menggunakan Kurikulum 2013 dikarenakan pada saat peneliti melakukan penelitian, guru-guru di SDN Taman 01 belum mendapat sosialisasi kurikulum 2013, informasi tersebut dapat diperoleh dari informan 1 sebagai berikut "Proses pembelajaran berupa RPP menggunakan kurikulum KTSP dan metode pembelajaran yang sering digunakan dalam membaca di kelas 1 adalah ceramah, tanya jawab, penugasan" (CL 1:2). Jadi dalam perencanaannya yaitu dengang RPP dan Silabus KTSP namun sudah memuat tahaptahap pembelajaran membaca permulaan dengan menggunakan model student facilitator and explaining dengan media buku cerita bergambar.

\section{Penerapan Model Pembelajaran Students Facilitator and Explaining}




\section{melalui Media Buku Cerita Bergambar}

Dalam penerapan model student facilitator and explaining terdiri dari beberapa tahap-tahapan. Huda (2014: 228-229) menyebutkan beberapa sintaks tahap-tahap model pembelajaran Student Faciltator and Explaining adalah:

1. Guru menyampaikan kompetensi yang ingin dicapai.

2. Guru mendemonstrasikan atau menyajikan garis-garis besar materi pembelajaran.

3. Guru memberi kesempatan kepada siswa untuk menjelaskan kepada siswa lainnya, misalnya melalui bagan atau peta konsep. Hal ini bisa dilakukan secara bergiliran atau acak.

4. Guru menyimpulkan ide atau pendapat siswa.

5. Guru menerangkan semua materi yang disajikan saat itu.

6. Penutup.

Dari tahapan-tahapan yang telah disebutkan di atas dapat ditarik kesimpulan bahwa tahapan-tahapan pembelajaran Student Faciltator and Explaining yaitu, guru menyampaikan kompetersi yang ingin dicapai, guru memeragakan atau menyajikan inti dari materi yang akan diajarkan, guru memberi kesempatan kepada siswa untuk menjelaskan kembali kepada teman lainnya, guru menyimpulkan pendapat siswa, dan guru menutup pembelajaran. Sedangkan penerapan media buku cerita bergambar buku cerita bergambar atau komik yaitu menggunakan suatu buku bacaan yang berisikan kartun yang mengungkapkan suatu karakter dan memerankan suatu cerita dalam urutan yang erat, dihubungkan dengan gambar dan dirancang untuk memberikan hiburan kepada para pembaca. Dan melalui bimbingan dari guru, buku cerita bergambar atau komik dapat berfungsi sebagai jembatan untuk menumbuhkan minat baca. Menurut
Rohani (2014: 78) dalam buku cerita bergamabar atau komik terdapat unsurunsur yaitu sederhana, langsung, aksiaksi yang cepat dan menggambarkan peristiwa-peristiwa yang mengandung bahaya, berisi unsur humor kasar, menggunakan bahasa percakapan, perhatikan kepada kriminalitas, kekuatan, keampuhan, adanya kecenderungan manusiawi yang universal terhadap pemujaan pahlawan.

Namun dalam menggunakan media buku cerita bergambar atau komik ada hal-hal yang perlu diperhatikan, baik dari segi bahasa maupun dari segi gambarnya. Menurut Angkowo dan Kosasih (2007: 31) pada gambar dalam buku cerita bergambar atau komik ada hal-hal yang perlu diperhatikan sebagi berikut:

1. Gunakan gambar yang sesuai dengan pertumbuhan dan perkembangan siswa (isi, ukuran, dan warna).

2. Saat memegang atau memperlihatkan gambar, usahakan agar gambar tersebut jangan samapai bergerak.

3. Hindari penggunaan gambar dalam jumlah dan jenis yang terlamapau banyak; sebab hal ini cenderung membingungkan siswa. Jika ingin membandingkan beberapa gambar, perlihatkanlah gambar itu satu per satu agar perhatian siswa hanya tertuju pada gambar yang sedang diamati.

4. Arahkan perhatian siswa pada sebuah gambar, kemudian ajukan beberapa pertanyaan langsung sehubungan dengan gambar tersebut.

5. Jika ingin memperlihatkan gambar pada siswa tanpa pengawasan khusus dari guru, usahakan agar ada keterangan tertulis pada bagian bawah dari gambar tersebut. Keterangan tersebut harus singkat tetapi jelas (tidak membuat siswa 
bingung dan bertanya-tanya pada dirinya sendiri atau orang lain).

6. Akan lebih baik lagi jika guru menulis pertanyaan-pertanyaan dan jawaban disamping suatu gambar, tetapi jawabannya ditutup dengan kertas. Biarkan setiap siswa menguji sendiri kebenarannya.

\section{Respon siswa terhadap model pembelajaranStudentsFacilitator and Explainingmelalui media buku cerita bergambar}

Respon siswa terhadap pembelajaran ini sangat beragam, banyak antusias dari mereka dalam mengikuti pembelajaran ini. Hal tersebut dikarenakan pembelajaran ini tergolong baru, model pembelajaran ini mengubah pola pikir siswa bahwa pembelajaran tidak harus dilakukan berpusat pada guru melainkan dapat pada siswa.

Selain itu juga siswa menyukai model pembelajaranStudentsFacilitator and Explaining dan media buku cerita bergambar ini sebab memiliki beberapa aspek maupun manfaat. Nilai-nilai yang terkandung dalam model pembelajaran Students Facilitator and Explaining didapat melalui rangkaian penyajian materi ajar yang diawali dengan penjelasan secara terbuka, melatih keberanian karena memberi kesempatan siswa untuk menjelaskan kembali kepada rekan-rekannya, melatih siswa bicara menyampaikan ide dan gagasan, dan melatih untuk berkerjasama dengan kelompoknya. Sedangkan nilai-nilai yang terkandung dalam media buku cerita bergambar yaitu sebagai media yang sangat penting digunakan dalam usaha memperjelas pengertian pada peserta didik. Sehingga dengan menggunakan gambar peserta didik dapat lebih memperhatikan terhadap benda-benda atau hal-hal yang belum pernah dilihatnya yang berkaitan dengan pelajaran, gambar dapat membantu guru dalam mencapai tujuan instruksional, karena gambar, pengalaman dan pengertian peserta didik menjadi luas, lebih jelas dan tidak mudah dilupakan, serta lebih konkret dalam ingatan dan asosiasi peserta didik (Sudjana dan Rivai dalam Angkowo dan Kosasih, 2007: 26).

Manfaat model pembelajaran Student Facilitator and Explaining dengan media buku cerita bergambar antara lain meningkatkan hubungan sosial dengan teman sebaya, melatih ketrampilan fisik, menumbuhkan kreativitas, sebagai sarana pembelajaran yang menarik, melatih keberanian siswa, melatih siswa untuk menyampaikan gagasan/ ide, dan membentuk kepribadian. Model Student Facilitator and Explaining merupakan model pembelajaran yang dilakukan secara berkelompok, oleh karena itu dapat meningkatkan hubungan sosial dan kerjasama dengan teman sebaya.

\section{Simpulan}

Dalam perencanaan model pembelajaran Students Facilitator and Explaining dengan menggunakan media buku cerita bergambar pada pembelajaran Bahasa Indonesia secara umum sudah baik. Guru telah merencakan dengan matang diantaranya dengan menyiapkan sejumlah perangkat pembelajaran seperti silabus, RPP, media, maupun perlengkapan yang dibutuhkan dalam pembelajaran. Pemilihan materi pun sudah dilakukan dengan baik. Pemilihan didasarkan pada bobot materi itu sendiri dan juga waktu yang dibutuhkan dalam permainan selain itu guru juga mempertimbangkan karakteristik dari siswa itu sendiri.

Model pembelajaran Students Facilitator and Explaining dengan menggunakan media buku cerita bergambar pada pembelajaran bahasa Indonesia secara umum sudah terlaksana dengan baik. Model pembelajaran Students Facilitator and Explaining dengan menggunakan media buku cerita bergambar yang dilakukan mampu memberikan dampak positif kepada siswa yaitu menumbuhkan keaktifan siswa dan antusiasme serta mengembangkan 
kemampuan berpikir siswa dalam memecahkan masalah dalam kelompok. Kerjasama siswa juga terbentuk dalam kegiatan berkelompok sehingga mampu menumbuhkan sikap positif terhadap siswa dalam interaksi sosialnya. Penerapan model pembelajaran Students Facilitator and Explaining dengan menggunakan media buku cerita bergambar ini dalam pelajaran bahasa Indonesia tergolong inovatif. Guru mampu membuat suasana berbeda dalam KBM, yang dulunya siswa kurang aktif menjadi saat KBM siswa aktif dan mendengarkan. Penerapan model pembelajaran ini mampu mengubah cara berfikir siswa bahwa pelajaran Bahasa Indonesia sekarang ini menjadi sangat menyenangkan. Materi yang sulit untuk diajarkan menjadi mudah dipelajari. Berdasarkan hasil wawancara, dokumentasi, observasi maupun pemberian angket. Respon siswa dikategorikan baik, antusias siswa dalam mempelajari pelajaran bahasa Indonesia menjadi meningkat.

\section{Daftar Pustaka}

[1] Asep Jihad dan Abdul Haris.2010.Evaluasi

Pembelajaran.Yogyakarta: Multi Persindo

[2] Ahmad Rohani. 2014. Media Instruksional Edukatif. Jakarta: PT Rineka Cipta.

[3] Agus Suprijono. 2015. Cooperative Learning Teori dan Aplikasi

Paikem. Yogyakarta: Pustaka Pelajar.

[4] Esti Ismawati dan Faras Umaya. 2012. Belajar Bahasa Di Kelas Awal. Yogyakarta: Ombak.

[5] Farida Rahim. 2006. Pengajaran Membaca Sekolah Dasar. Jakarta: PT Bumi Aksara.

[6] Harjanto. 2011. Perencanaan Pengajaran.Jakarta: Rineka Cipta

[7] Henry Guntur Tarigan. 2008. Membaca Sebagai Suatu Ketrampilan Berbahasa. Bandung: Angkasa.
[8] Lexy J.Moleong. 2014. Metodologi Penelitian Kualitatif. Bandung: PT Remaja Rosdakarya Offset.

[9] Miftahul Huda. 2013 Model-Model Pengajaran Dan Pembelajaran IsuIsu Metodis Dan Paradigmatis. Yogyakarta: Pustaka Pelajar Offset.

[10] Nana Sudjana. 2011. Penilaian Hasil Proses Belajar Mengajar. Bandung: PT Remaja Rosdakarya

[11] Nana Syaodih Sukmadinata.2011. Metode Penelitian Pendidikan. Bandung: PT Remaja Rosdakarya.

[12] Nunuk Suryani Dan Leo Agung. 2012. Strategi Belajar Mengajar. Yogyakarta: Ombak.

[13] Robertus Angkowo dan A. Koasih. 2007. Optimalisasi Media Pembelajaran. Jakarta: PT Grasindo.

[14] Suharsimi Arikunto. 2010. Prosedur Penelitian Suatu Pendekatan Praktik. Jakarta: Rineka Cipta

[15] Sudaryono, Gaguk Margono, Wardani Rahayu. 2013.

Pengembangan Instrumen

Penelitian Pendidikan. Yogyakarta: Graha Ilmu.

[16] Sugiyono. 2013.Metode Penelitian Pendidikan Pendekatan Kuantitatif, Kualitatif, dan $R \& D$. Bandung: ALFABETA,cv

[17] Sugiyono. 2014. Memahami Penelitian Kualitatif. Bandung: AlfaBeta

[18] Yunus Abidin. 2012. Yunus Abidin. 2012. Pembelajaran Bahasa Berbasis Pendidikan Karakter. Bandung: PT Refika Aditama.. Bandung: PT Refika Aditama.

[19] Zainal Arifin. 2012. Penelitian Pendidikan Metode dan Paradigma Baru. Bandung: PT Remaja Posdakarya.

[20] Zainal Aqib. 2013. Model-Model, Media Dan Strategi Pembelajaran Kontekstual (Inovatif). Bandung: Yrama Widya. 


\section{Profil Penulis}

Endang Sri Maruti lahir di Ponorogo, 01 Januari 1988. Pendidikan sarjana diselesaikan tepat waktu di Universitas Negeri Surabaya program studi Pendidikan Bahasa Daerah (Jawa) lulus tahun 2011, dan langsung melanjutkan studi master di almamater yang sama dengan program studi Pendidikan Bahasa dan sastra Indonesia (dan Daerah) dan lulus pada tahun 2013. Setelah berhasil meraih gelar Magister, penulis langsung mengabdikan diri dan mengembangkan bidang keilmuannya dengan menjadi tenaga pendidik di program studi Pendidikan Guru Sekolah Dasar (PGSD) IKIP PGRI Madiun pada tahun 2013-2017, yang pada tahun 2017 berubah menjadi Universitas PGRI Madiun. 